$S_{523}$

$\mathrm{H}_{76}$ 



\section{ADDRESS}

OF

\section{F. HOUSTON}

Secretary of Agriculture

BEFORE THE

Association of American Agricultural Colleges and Experiment Stations

AUDITORIUM HOTEL

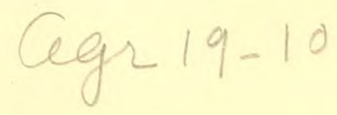

Chicago, Ill., November 12, 1919

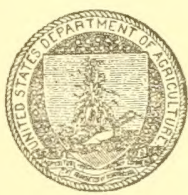

UNITED STATES DEPARTMENT OF AGRICULTURE

CIRCULAR 147

OFFICE OF THE SECRETARY 
$55^{2}+\lambda^{3}$

D. 012

MA $12 \quad 1920$

$\because \vdots \vdots$ 


\title{
ADDRESS OF D. F. HOUSTON,
}

\author{
SECRETARY OF AGRICULTURE.
}

BEFORE THE ASSOCIATION OF AMERICAN AGRICULTURAL COLLEGES AND EX. PERIMENT STATIONS, AUDITORIUM HOTEL, CHICAGO, ILL., NOVEMBER 12, 1919.

$\mathrm{O}$

NE YEAR AGO yesterday word came across the ocean that the armistice had been signed and that hostilities had ceased. Throughout the Nation celebrations were quickly organized and the people rejoiced. And they had good reason for rejoicing; for the strong enemy of free peoples had been crushed and the wholesale ciestruction of human beings had ended. Doubtless few of them dreamed that at the end of a year the Nation still would not have peace. To-day there is for us and other peoples neither peace nor war: and there is not only the unrest, which is the natural heritage of war, but also the uncertainty and added difficulties which exist because of the failure finally to conclude peace. Few students of history imagined when the armistice was signed that this Nation or the world would quickly return to a stable condition. History clearly teaches the impossibility of quick adjustments after great wars. The Napoleonic war was followed by a long period of turmoil; and the difficulties for half a generation after our Civil War are fresh in the minds of many of us. Still there were few of us who did not anticipate an earlier completion of the formal peace processes and a prompt exclusive devotion of governments to the work of liquidating the war.

\section{WORLD IN STATE OF DOUBT.}

It is not my purpose or desire to attempt to assign responsibility for the delay in making peace; but I may note, as we all must, the results of the delay. The whole world remains in a state of doubt and hesitation. The people of the new nations particularly can not make their plans with any confidence, because some of them do not yet know what their alignments will be or what kind of peace will exist when it does come. With the Central Powers our commercial relations have not yet been reestablished. In them we have no consular or trade agents, while some of the Allies, having ratified the treaty of peace, are laying their plans to occupy the commercial 
fields of Germany and Austria and are already engaged in trade with them. The dificulties of our situation are daily brought home to people throughout the Union, and particularly to executive and legislative officer's; and the handicaps we shall suffer by additional delay are obvious. We are unable to deternine the scale of our Military and Naval Establishments, intelligently to make a financial budget, or to plan our scheme of taxation. If the League of Nations is to be a reality there is prospect of very considerable disarmament, with a consequent reduction in expenditure and taxation. It is imperative that this should occur. The war has shown clearly what military preparation means and what sort of armament we shall be compelled to maintain if a competitive military régime is to persist. Where, before the war, oni Military Establishment entailed a burden of two or three hundred millions of dollars, it will hereafter, on a competitive basis, involve expendiures of not less than a billion and a half. Further embarrasment results from the fact that there is no way of determining the duration of emergency legislation. There are statutes which expire with the prociamation of peace. This may happen in two weeks or two years, and, therefore, business men and administrative officers do not know how to make their plans and form judgments. Production programs of all sorts are fundamentally affected and disturbed conditions furnish agitators farorable opportunities for conducting their vicions propaganda. Obviousiy, the existing state of things makes for ineffectiveness of national life in every direction and the persistence and perhaps extension of present burdens and sacrifices.

\section{UNREST LESSENING PRODUCTION.}

The present industrial unrest, in part a heritage of the war, is aggravated by our state of uncertainty. It is mounting higher and is crippling production at the very time when a paramount need of the Nation and of the world is a scaling down of prices and a reduction of the cost of living which, in the main, can result only from increased production and thrift. Practices are resorted to which greatly increase the already heavy burdens of industry and thwart the efforts of private and governmental agencies to furnish relief. Increased wages are demanded to meet the high cost of living and higher prices are asked to cover increased cost; and so the Nation faces a process of pyramiding, which, if not checked, will lead to industrial collapse and untold suffering. I do not undertake to pass judgment on the strike as a weapon for labor in normal times. But one thing is certain. In existing circumstances, it can only check production, lessen the volume of national wealth to be distributed, and increase the cost of living, not only for labor but for all the other citizens of the Republic. Another thing is certain. It is 
not a remedy to which labor ought to be forced to resort. It is a crude way of settling a dispute, as war is; and it is not creditable to us as a Nation that we can not find another and better way- that we can not establish conditions which will make a strike a thing of the past. All the people of the Nation are bearing the burden imposed by reduced production and no one class in society can hope to escape it as the expense of all other classes. "We must unite, not divide, to correct the evil." This Nation needs now to feel the patriotic impulse quite as much as it did during the war. If the preservation of the liberties of the Nation was worth fighting for surely the opportunity victory has brought to pursue unhindered the tasks of improvement should call out our best impulses. Peace has her need for patriotism no less intense than war; and the trouble seems to be with us, as Lloyd George said of the English people, that we have demobilized patriotism too soon.

\section{EFFECT ON FARMERS.}

Present conditions bear with peculiar weight on the farmers of the Nation. It is not improbable that natural economic forces operating during the ensuing 12 months will produce a slow decline in prices and that, in spite of anything that can be done, the reduction may be more marked in the case of agricultural products. This may result from the fact that agricultural production during the war was not only maintained but extended, while industrial production for nonmilitary purposes decreased in some directions; that Europe may recover more rapidly agriculturally than industrially; and that the opening up of shipping will bring back into the markets of Europe the products of more distant nations. It is reasonably clear that Europe will be hard pressed for food supplies, at least until after the harvest of 1920 . Russia is likely to be a negligible factor so far as exports of foodstuffs to other nations are concerned. European countries in the aggregate probably will not produce this year more than 70 per cent of their prewar normal output. Apparently Poland, Austria proper, and Italy will be in especially difficult circumstances; and all the central and western European nations will be compelled to import large quantities of cereals and meat products. The quantities they can secure will be limited, in part, by their impaired ability to pay for them. They are seeking credits not only for food supplies but also for raw materials for their industries. Obviously, they can devote only a part of the credits they receive to the purchase of foods. Unquestionably, they will attempt to obtain these in the cheapest markets. Before the European war Great Britain, the principal food-importing nation, secured most of her beef from her colonies and from Argentina. In 1913 her' imports of beef from Argentina and Australia amounted to over 
$8,500,000,000$ pounds. They decreased during the war until in 1918 she was receiving from these countries only $2,5555,000,000$ pounds, while, on the other hand, her imports from the United States rose in the same period from $1,462,000$ pounds in 1913 to $3,583,000,000$ in 1918. Shipping is opening up again and there are indications that the United Kingdom is once more turning to her former sources for supplies of beef. The exports of beef (including oleo oils) from this country to the United Kingdom during July of this year aggregated $5,300,000$ pounds as against $72,000,000$ in June, 1918 , while the exports of pork (including lard) during July of this year amounted to $154,000,000$ pounds as against 220,000,000 in June, 1919. Although the United States will be called upon to furnish Europe large supplies of food, certainly until after the next harrest, it appears that there is already a tendency for the exports of certain products to decline; and it may be, if Europe has good seasons next year, that our exports may return toward the prewar normal. We shall soon be concerned with the planting program of our farmers for the spring of 1920. In view of all the circumstances, it seems that it would be wise for the same suggestion to be made to them as was made in the early part of the year, namely, that they should practice safe farming, returning to a balanced agriculture and to the operations best suited to their own individual and community conditions.

While economic forces may be the main factors in reducing the prices of farm commodities, they will not be obvious to many people; and there will be a disposition to attribute any drop in prices to the action of Govermment or of private agencies. The impression seems to have got abroad that the Government was concerning itself only with the prices of foodstuffs and that the farmer would be hit first and exclusively. That such was the Government's intention is, of course, far from the truth. Its object was primarily to prevent profiteering in all the necessaries of life and it is as much concerned in preventing profiteering in manufactured products as in food products. The Attorney General, in seeking power to deal with the problem, asked Congress to extend the control act to cover manufactured necessaries, which was done, and has instructed his agents to give special attention to dealers in such commodities.

\section{EVERY PRODUCING CLASS MUST DO ITS PART.}

The trouble is that the press in discussing the cost of living thinks almost exclusively in terms of food and limits its statements principally to such products. The difficulty has been increased by the fact that not a few business men have asserted that the cost of living can not be reduced unless the prices of foodstuffs fall, and that the prices of foodstuffs will not fall unless there is greatly increased production. Obviously, it is useless and unjust to ask farmer's 
to increase production, buying what they have to buy at the present scale of prices, with the intimation that, at the end of the crop year, their products will fall in price and that then the manufacturers will consider what they can do in respect to their products. Certainly it is desirable to return to a stable condition at as early a date as possible. Every class of producers in the country must do its part and manufacturers should be willing to make at least a contemporaneous reduction in the prices of their products.

\section{SOME PREREQUISITES FOR RURAI CONTENTMENT.}

Many people ignorant of rural problems talk and write as if farming were not a business and as if food production did not involve the expenditure of capital and labor. The demand of the city is for cheap food and that more abundantly. There are those who talk as if there could be an unlimited number of farmers. This may have been true when the farm was self-sufficient and produced little or no surplus. But, obviously, to-day there should be, and, in the long run, there will tend to be, enough farmers to produce their proportion of what the world will buy at prices which make production profitable. Certainly farming must pay. There will be farmers enough if the business of farming is made profitable and if rural life is made attractive and healthful. The farmer, as well as the industrial worker, is entitled to a living wage and to a reasonable profit on his investment. He is entitled also to satisfactory educational opportunities for his children and to the benefits of modern medical science and sanitation. When these requirements are met there will be no difficulty in retaining in the rural districts a sufficient number of contented and efficient people. What we need is not back-to-the-land propaganda, but an acceleration of the work for the improvement of the countryside which will render the abandonment of farms unnecessary and the expansion of farming inevitable. I am sure that the farmers of the Nation are perfectly willing to do their part in producing and saving if all other producers in the Nation will set about doing their part.

\section{NEED FOR FRESH RURAL SURVEY.}

Present conditions, and particularly present states of mind, indicate the need of a fresh, broad survey of rural life, of its special problems, and of its relationships. It should be viewed as a whole. A comprehensive flexible program should be developed for the guidance of the different agencies, each of which has its peculiar functions and responsibilities. Furthermore, the principles and purposes governing agricultural life and agencies should be set forth for the education of the American public, particularly the urban part of it. The Nation as a whole needs a fuller appreciation 
of its basic industry, and a more definite sense of direction of its efforts to foster it. Many agencies are now following more or less well-defined, helpful plans of their own devising, but these are at best piecemeal, and there is confusion of leadership and objectives. A program made by any one element would be partial and unsatisfactory. We should have a meeting of minds of all those directly concerned, of farmers, of agricultural leaders, and of business men. This need was ably presented by your president, Dean Darenport, and by Dr. Butterfield, and I need not enter into details. My present suggestion is that there should first be held a relatively large conference, and that the matter of setting up a small temporary or permanent commission be then determined.

The calling of such a conference is very definitely in the President's mind. In connection with the recent industrial conference, he anthorized me to make it known that he intended to ask for another meeting which would deal especially with problens which more intimately concern farmers. The industrial conference was expected to consider only the problem of the relation of employers to employees in manufacturing, and he invoked the aid of six agricultural representatives to assist in its solution, deeming this number adequate in the circumstanes. The conference now suggested would, of course, call for a very generous representation of farmers and agricultural leaders.

\section{SERVICE OF COLLEGES.}

I keenly recognize that the agricultural colleges of the States, like the Federal department itself, are now confronted with unusual difficulties and are laboring under serious enbrrassments; and yet in the midst of these they are called upon to render even more urgent service. I have long had an exalted opinion of the value of these institutions to our democracy. Recent events have caused me even more highly to prize then and more clearly to recognize their need. They have made it singularly clear that agricultural institutions must omit no step to add, through research and experiment, to the sim of our scientific knowledge. In some instances, available information has proven to be fragmentary. In others there were no results at hand on which to base intelligent conclusions. Up to a short time ago investigation had seemed to rum ahead of facilities for conveying information; but with the improvement in publication actirity, the expansion of the agricultural press, and particularly the firm establishment of the extension service, the danger is now rather that our teaching may outruin the accumulated stock of knowledge and become sterile. Of conrse, neither the problems of production nor those of distribution hare been solved. As economic conditions change and become more complex new and vital research 
problems will arise. The Nation should have a well-balanced program not only of instruction but also of research. To this end, it must secure and retain the services of its most talented scientific and practical men; and this means something in terms of dollars and cents. It means that we must not only place the investigator on a higher financial plane but also give those who have talent funds and facilities in generous measure. It is increasingly clent that, in all positions of responsibility, the State and the Nation must be prepared to secure and retain men of the requisite training and experience and to make the conditions sufficiently attractive. Our democracy is to-day threatened with inefficient service because of its failure to provide a reasonably decent compensation for men of capacity charged with large responsibilities, and our democratic arrangements may either break down or result in commonplace performance, if reasonable requirements are not met.

\section{SAFEGUARDING DEMOCRACY.}

But the agricultural colleges of the country owe a duty outside their technical field, outside their fields of inrestigation and technical education. They are charged, as I conceive it, with something more even than the task of improving farming. Present conditions point to the need of leadership along broader lines in rural as well as in urban districts. We can not too frequently refresh the minds of all our people as to the nature and meaning of democracy. of our governmental institutions and ideals; and there is in rural districts, as well as in urban, a considerable body of people, many of them recently come among us, unacquainted with our institutions and purposes, familiar only with conditions radically different from ours, who certainly need a sympathetic induction into American life and the most energetic assistance that all our educational institutions can furnish.

Some of them need more than this. They need to be taught the very elements of democracy and the meaning of the rule of law. The people of this country are committed to the rule of the majority and to the rule of law. There is no good cause which can not get a hearing from our people. It is the privilege of men who advocate it to persuade the majority that they are right. If they can, they can secure what they seek at the polls. If they can not, they must abide by the will of the majority or suffer the penalty. Not to do so is treason to the majority. The majority will not tolerate any effort of a misguided minority to impose its will by violence. It does not intend to live under the spell of threats and menaces. And the average American will not be patient with those who say that if they do not like a law they may not obey it. 


\section{NO CLASS RULE.}

Nor will the American people have any patience with those who adrocate the dominance or rule of any class. Democracy arose on the downfall of a class. Our forefathers did not want class rule. They deposed such autocrats as the Stuarts, the Bourbons, and their adherents, who sought to tyrannize over the masses. There is no one class in society that has sense enough to rule all the others. Any one class would make a sad failure of gorerning this Nation or any other. History teaches that lesson very plainly. I am in favor of improving our Govermment whenever the need for improvement is demonstrated, but not of upsetting it. There will and must be changes, but these changes must be discussed and made according to the processes of law and of American life and institutions, and not according to the whim of some class. The American people are still committed to the theory of representative gorernment, of government made up of representatires of all the people. I do not beliere they will substitute for it representation of groups of interests, with a struggle on the part of each group to dominate; and I think that they will not accept the theory that employees of the Government, municipal. State, or Federal, may strike to secure what they wish. I am unable to see how a group of individuals can claim the privilege of striking against the body politic withont arrogating to itself the position of supremacy orer the people. It is time for very plain speaking and for the inculcation of some very commonplace truths. We are all in sympathy with rational proposals for the improvement of the masses of the less fortunate people of the Nation and of the world, but this improvement must come by orderly processes. And we must recognize that, after all, the real progress of humanity is slow. In times like these, progress is rapid, but not so rapid as it seems to some. During great uphearals, people have not infrequently thought that they have got very much further than they actually have. They have got more ont of the experience than there was in it. France did this at the end of the eighteenth century, when she enthroned reason, and thought that she had got, in a few years, to a point she has not yet reached. Russia is now making the same blunder.

\section{STANDARDS OF CONDUCT.}

What we need is cool judgment, open minds, regard for facts, and courage to follow conclusions based on them. These characteristics the institutions of learning of the Nation are peculiarly fitted to inculcate. Let us have debate, criticism, and progress by all means, but let us have constructive criticism, and let us have progressives who know where they are headed and why. Let us demand that our pub- 
lic men and the agencies whose task it is to inform and lead public opinion, shall show a conscientious regard for facts and give the people helpful interpretations of them. This is no time for mere partisan tactics, for personal abuse, and for misrepresentation of men, policies, and institutions. Mer of any party in responsible positions, or of the press, who make statements which they know are not true-or, what is quite as pernicious and more common, statements they do not know to be true-only contribute to the spirit of unrest and irritation and tend in no small measure to furnish justification to ignorant or evil-minded persons among us for their acts of violence and crime. They assume a grave risk and will not escape their share of responsibility for what may happen.

I confidently call upon the unirersities and colleges here represented more energetically to lead the educational forces of the Nation in the patriotic task of leeping before the minds of all our people the meaning and value of our institutions, of Americanizing our population of recent foreign extraction, of strengthening our useful national habits of thought, and of holding our publicists and public men to high standaris of utterance and action. 
LIBRARY OF CONGRESS

|||||||||||||||||||||||||||||||||||||||||||||

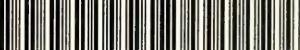

00027438921 